\title{
Relative importance of water column vs zooplankton variables in the determination of late-stage larval fish assemblage structure in coastal waters of a coral reef lagoon
}

\author{
LAURE CARASSOU and DOMINIQUE PONTON \\ Institute of Research for the Development (IRD), Research Unit 128, BP A5, 98 848, Nouméa cedex, New Caledonia. \\ E-mail: laure.carassou@ noumea.ird.nc
}

\begin{abstract}
SUMMARY: The relationship between fish larvae and their zooplanktonic prey has not been fully explored for late-stage larvae of coral-reef fish in lagoonal environments. However, compared to most temperate taxa, these larvae are characterized by strong sensory and swimming abilities, which may influence their feeding behaviour in the water column. The present study aims to determine the relative importance of the water column and zooplankton variables for the structure of pre-settlement larval fish assemblages within a single season in three bays of the coral reef lagoon of New Caledonia, southwest Pacific. The structure of larval assemblages was found to be explained better by water column variables in two out of the three bays examined. Zooplankton variables only played a role in one bay out of the three, probably due to the lower variability in the water column variables. Moreover, the relationship between total larval fish abundance and zooplankton density was not significant in any of the three bays. These results suggest that the relationship between late-stage coral-reef fish larvae and their prey: 1) is difficult to detect at small spatial and temporal scales, 2) is probably complex and non-linear, 3) depends on environmental conditions, and 4) probably varies between fish taxa.
\end{abstract}

Keywords: late-stage coral-reef fish larvae, zooplanktonic prey, water column properties, bays, spatial and temporal scale.

RESUMEN: IMPORTANCIA RELATIVA DE LAS VARIABLES DE LA COLUMNA DE AGUA VS LAS DEL ZOOPLANCTON EN LA DETERMINACIÓN DE LA ESTRUCTURA DE LOS GRUPOS DE LARVAS DE PECES EN ÚlTIMA FASE DE DESARROLLO EN LAS AGUAS COSTERAS DE UNA LAGUNA DE ARRECIFE CORALINO. - La relación entre las larvas de peces y sus presas zooplanctónicas sigue siendo poco estudiada para las larvas en últimas fases de desarrollo de peces coralinos en ambientes lagunares. Además estas larvas se caracterizan por tener grandes habilidades natatorias y sensoriales respecto a la mayoría de peces en mares templados, habilidades que pueden influenciar su comportamiento alimenticio en la columna de agua. El presente estudio tiene como objetivo determinar la importancia relativa de las variables de la columna de agua y del zooplancton sobre la estructura de las larvas de peces próximas al asentamiento durante una única estación y en tres bahías de la laguna coralina de Nueva-Caledonia en el Pacífico sur. La estructura de los grupos de larvas de peces se explica mejor por las variables de la columna de agua en dos de las tres bahías estudiadas, pero las variables zooplanctónicas desempeñan un papel importante en la tercera bahía, seguramente debido a la mayor variabilidad de las condiciones de la columna de agua. La relación entre la abundancia total de las larvas de peces y la densidad total del zooplancton no fue significativa en ninguna de las tres bahías. Estos resultados sugieren que la relación entre las larvas de peces coralinos en última fase de desarrollo y sus presas es 1) difícilmente detectable a tan pequeña escala espacial y temporal, 2) probablemente compleja y no lineal, 3) variable según las condiciones medioambientales y 4) probablemente variable según los taxones.

Palabras clave: larvas de peces coralinos en última fase de desarrollo, presas zooplanctónicas, propiedades de la columna de agua, bahías, escala espacial y temporal. 


\section{INTRODUCTION}

According to the "match-mismatch" hypothesis (Cushing, 1975, 1990), the temporal co-occurrence of fish larvae and their prey is responsible for the variability in larval survival rates, and thus for the interannual variations in recruitment success. A number of other hypotheses based on this concept have been developed. The "migration triangle" hypothesis (Harden-Jones, 1968), for example, proposes that water currents influence the ability of fish larvae to reach nursery areas where their spatial distribution fits that of zooplankton. The postulate that larval survival improves when the distribution of larvae and that of their prey are closely related is now widely accepted and has indeed been demonstrated in some studies (Hartmann, 1983; McCormick and Molony, 1992). More generally, significant relationships between larval fish abundance and zooplankton density have been observed in a number of case studies and for particular larval fish species in temperate ecosystems (Brander et al., 2001; Pepin et al., 2003; Voss et al., 2006). However, in spite of its significant ecological relevance, our current knowledge on the relationships between total larval fish abundance and total zooplankton biomass or density is still limited (Sanvicente-Añorve et al., 2006).

Furthermore, little is known about how these concepts apply to tropical ecosystems. There have been some studies on the temporal and spatial cooccurrences of tropical fish larvae and their prey (Houde and Lovdal, 1984; Meekan et al., 2006), but these rely on observations of young, and thus poorly developed, larvae that can be considered to be passive drifters. The results can hardly apply to late larval stages of coral reef fish, which are known to actively control their horizontal and vertical position (Doherty and Carleton, 1997) with their highly developed sensory and swimming abilities (Fisher and Bellwood, 2002). Furthermore, little is known about the relationships linking the distribution of larval fish and that of zooplankton at small spatial and temporal scales in tropical ecosystems.

In the context of a broader study that aimed to understand the relationships between late-stage larval fish assemblages and the environmental conditions in the lagoon of New Caledonia (see Carassou and Ponton, 2007; Carassou et al., 2008, for details of the whole study), samples of fish larvae and zooplankton were simultaneously collected in various locations of the lagoon. These studies demonstrated that the majority of late-stage larvae collected in the lagoon of New Caledonia, regardless of their taxa, feed on similar pelagic micro- and mesozooplankton organisms (Carassou, 2008). Moreover, coastal embayments appear to harbour high densities of food items for late-stage fish larvae (Carassou, 2008), and larval fish assemblages that are different from those observed in lagoonal areas (Carassou et al., 2008).

The objective of the present study was thus to determine the respective roles played by the water column conditions and the availability of zooplankton in the spatial and temporal distributions of late-stage fish larvae in three different bays. For this purpose, the water column conditions, the amount and composition of zooplankton and the abundance of larval fish families observed in each bay were analyzed over a five month period. The correlations between various sets of environmental and zooplankton variables and larval fish abundances were then addressed. Finally, the relationship between total larval fish abundance and total zooplankton density was tested.

\section{MATERIAL AND METHODS}

\section{Study sites and sampling period}

Sampling took place in three bays located on the south-west coast of the main island of New Caledonia. The first two bays to be considered lie approximately $100 \mathrm{~km}$ north of Nouméa. The Bay of Chambeyron (hereafter called Chambeyron) is characterized by muddy bottoms, and is exposed to dominant winds from the south-east (Fig. 1a). The nearby muddy Bay of Ouaraï (hereafter called Ouarai) is protected from the dominant winds from the south-east by the Lebris peninsula, and is affected by the freshwater inputs of the La Foa River (Fig. 1a). Both bays lie approximately $7 \mathrm{~km}$ from the barrier reef. The third bay selected for this study is the large Bay of Dumbéa (hereafter called Dumbéa), located a few kilometres north of Nouméa, over $20 \mathrm{~km}$ from the barrier reef. It is characterized by muddy bottoms covered by living colonies of branched corals, and is influenced by the freshwater discharge of the La Dumbéa River (Fig. 1b).

Sampling was performed from September 2005 to January 2006, which is the warm season when larval fish are abundant in the lagoon (Carassou and Ponton, 2007). Two stations were sampled during four successive nights per month in Chambeyron 
a)

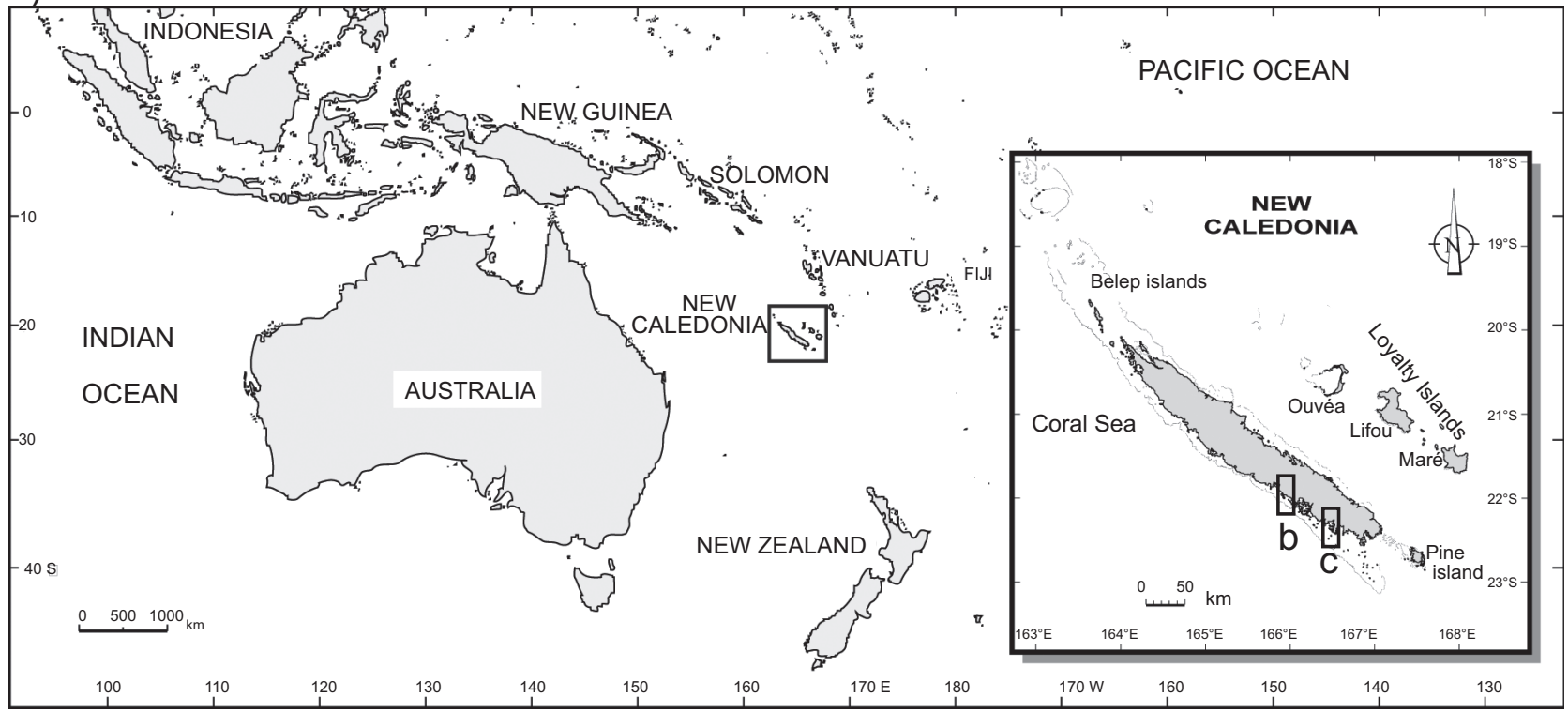

b)

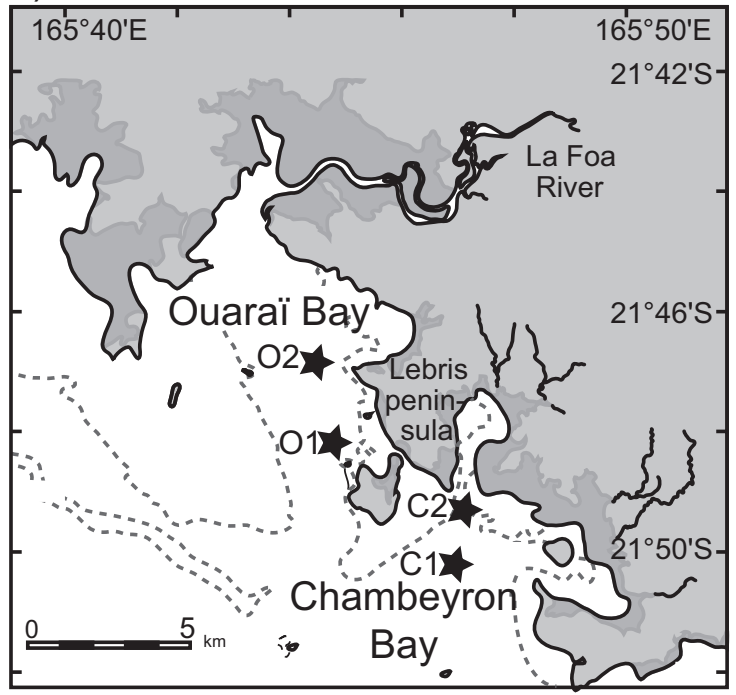

c)

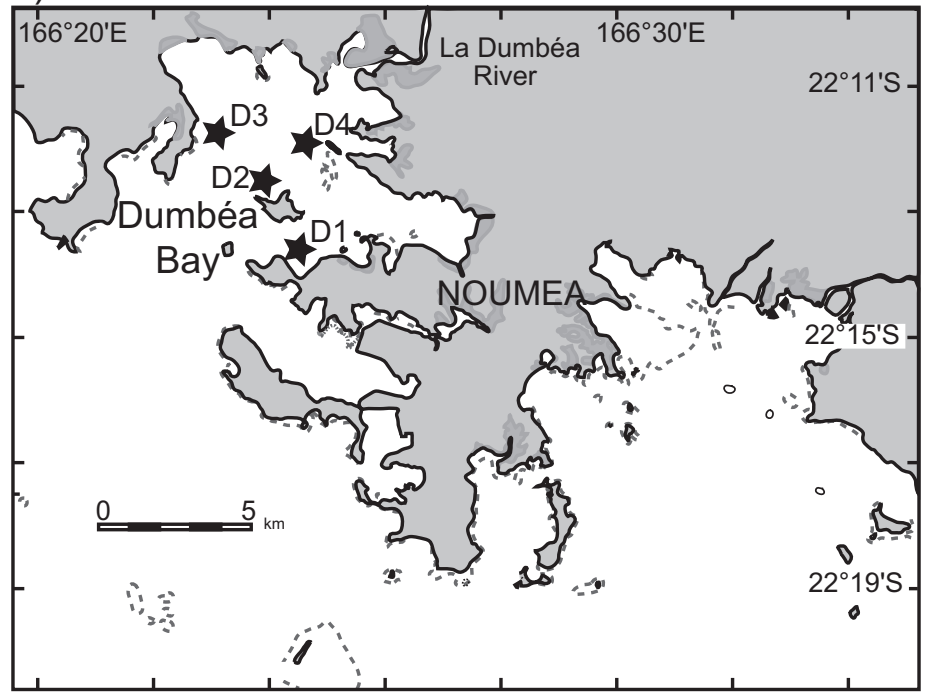

FIG. 1. - Position of New Caledonia in the southwest Pacific (a), and of the sampling stations (stars) in Chambeyron Bay and Ouaraï Bay (b) and Dumbéa Bay (c), southwestern New Caledonia. The dotted lines indicate the position of the reefs; the dark grey zones on the land indicate the position of the mangroves.

and Ouaraï, and four stations were sampled two successive nights per month in Dumbéa, providing a total number of 40 samples per bay ( 8 samples per bay and per month).

\section{Sampling design}

Fish larvae were collected using light-traps developed by the Aquafish Technologies Company, Lattes, France, and described in detail in Carassou and Ponton (2007). Light-traps were chosen because, unlike plankton-nets that can be easily avoided by late-stage fish larvae (Choat et al., 1993; Wilson,
2001), these gears are known to be efficient for synoptically collecting photo-tropic developmental stages of coral-reef fishes (Doherty, 1987). The light-traps were set at dusk, at a depth of $2.5 \mathrm{~m}$. A timer switched the lamp on automatically for four hours each night, from 1:00 to 5:00 am. The sampling periods were centred around the new moon to optimize the efficiency of the light-traps. Upon retrieval, fishes were anaesthetized in $0.75 \mathrm{~g} \cdot \mathrm{l}^{-1}$ benzocaine and immediately preserved in $95 \%$ alcohol.

At the same time that the light-traps were set at dusk, the zooplanktonic prey of fish larvae, represented by micro- and meso-zooplankton assemblages 
(Sampey et al., 2007), were collected at each station. Only zooplankton from surface waters was sampled since most taxa of coral-reef fish larvae distribute in deep waters during the day, and aggregate in surface waters where they feed during the night (Haney, 1988; Leis, 1991). A $60 \mu \mathrm{m}$ mesh, $1.60 \mathrm{~m}$ long and $20 \mathrm{~cm}$ in diameter, plankton-net was towed approximately 0.5 $\mathrm{m}$ below the water surface by a boat that followed a circular trajectory for two minutes at approximately two knots. A General Oceanic flowmeter provided an estimate of the distance travelled and thus of the filtered water volume (in $\mathrm{m}^{3}$ ) by assuming 100\% filtering efficiency. The plankton-net samples were immediately preserved in $10 \%$ formaldehyde.

Three water samples were collected at each station with a Niskin bottle in order to measure: (1) the concentration of chlorophyll $a\left(\mathrm{Chl} a\right.$, in $\left.\mu \mathrm{g} \cdot l^{-1}\right)$, (2) the relative abundance of pheophytine (\%pheo, in \%), (3) the concentration of particulate organic carbon (POC, in $\mu \mathrm{M} \cdot \mathrm{l}^{-1}$ ), (4) the concentration of particulate organic nitrogen ( $\mathrm{PON}$, in $\left.\mu \mathrm{M} \cdot \mathrm{l}^{-1}\right)$, (5) the concentration of particulate organic phosphorous (POP, in $\mu \mathrm{M} \cdot 1^{-1}$ ), and (6) the carbon/nitrogen ratio $(\mathrm{C} / \mathrm{N})$. At each station, the water samples were collected (Table 1) at the surface, at mid-depth, and one meter above the bottom. The three samples were mixed in order to provide a mean value for the water column. Sampling took place at the same time that the light-traps were retrieved in at dawn and the samples were immediately placed in a cooler at approximately $0^{\circ} \mathrm{C}$ for a maximum of two hours. Once back on shore, sub-samples varying between 250 and $700 \mathrm{ml}$ were filtered with $25 \mu \mathrm{m} \mathrm{GF} / \mathrm{F}$ Whatman filters. The filters were immediately frozen and later analyzed following the method by Aminot and Kérouel (2004). The temperature (in ${ }^{\circ} \mathrm{C}$ ), salinity and turbidity (in FTU) were recorded at each sampling station from the surface to the bottom using a SBE19 Seabird CTD before and after fish sampling (Table 1).

\section{Laboratory work}

The fish larvae were identified to the family level using the meristic, morphological and pigmentation criteria described in Leis and Trsnki (1989) and Leis and Carson-Ewart (2000). The standard length (SL) of all individuals was measured to the nearest 0.1 $\mathrm{mm}$, except for the very abundant Clupeidae and Engraulididae for which a maximum of 30 randomly selected individuals per family and sample were measured.

The zooplanktonic organisms were counted under a microscope (magnification $\times 125$ ) in three subsamples poured into a $101.8 \mathrm{~mm}^{3}$ counting cell (ref. $\mathrm{n}^{\circ} 9948$ Thomas Company, Philadelphia, USA). All organisms were counted, but only the organism categories which have been shown to constitute the major prey items consumed by fish larvae in the lagoon of New Caledonia were retained: small copepods (copepodids), nauplii of copepods, eggs and lumps of eggs of copepods, mollusc larvae, includ-

TABLE 1. - Mean values of water column and zooplankton variables from September 2005 to January 2006 in the Bay of Chambeyron (Cham), the Bay of Ouaraï (Ouar) and the Bay of Dumbéa (Dumb), with corresponding abbreviations and units.

\begin{tabular}{|c|c|c|c|c|c|}
\hline Variable & Abbreviation & Unit & Cham & Ouar & Dumb \\
\hline \multicolumn{6}{|l|}{ Water column } \\
\hline $\begin{array}{l}\text { Mean surface temperature }(0-5 \mathrm{~m}) \\
\text { Mean surface salinity }(0-5 \mathrm{~m}) \\
\text { Mean surface turbidity }(0-5 \mathrm{~m}) \\
\text { Chlorophyll } a \text { concentration } \\
\text { Proportion of pheophytine (i.e. degraded chlorophyll) } \\
\text { Particulate Organic Carbon concentration } \\
\text { Particulate Organic Nitrogen concentration } \\
\text { Particulate organic Phosphorous concentration } \\
\text { Ratio carbon/nitrogen }\end{array}$ & $\begin{array}{l}\text { temp } \\
\text { sal } \\
\text { turb } \\
\text { Chl } \\
\text { \%pheo } \\
\text { POC } \\
\text { PON } \\
\text { POP } \\
\text { C/N }\end{array}$ & $\begin{array}{l}{ }^{\circ} \mathrm{C} \\
\text { psu } \\
\text { FTU } \\
\mu \mathrm{g} \cdot l^{-1} \\
\% \\
\mu \mathrm{M} \cdot \cdot^{-1} \\
\mu \mathrm{M} \cdot l^{-1} \\
\mu \mathrm{M} \cdot 1^{-1}\end{array}$ & $\begin{array}{c}25.4 \\
36.0 \\
1.7 \\
0.6 \\
29.4 \\
21.2 \\
3.0 \\
0.1 \\
7.5\end{array}$ & $\begin{array}{c}25.1 \\
35.7 \\
2.6 \\
0.9 \\
26.9 \\
30.8 \\
3.9 \\
0.2 \\
8.6\end{array}$ & $\begin{array}{c}25.0 \\
35.5 \\
2.3 \\
0.5 \\
28.9 \\
11.1 \\
1.3 \\
0.1 \\
9.1\end{array}$ \\
\hline \multicolumn{6}{|l|}{ Zooplankton } \\
\hline $\begin{array}{l}\text { Total zooplankton density } \times 10^{4} \\
\text { Settled volume of zooplankton } \\
\text { Small Copepods (copepodids) density } \times 10^{4} \\
\text { Eggs and egg lumps density } \times 10^{4} \\
\text { Nauplii density } \times 10^{4} \\
\text { Mollusc veligers density } \times 10^{4} \\
\text { Small unidentified crustaceans density } \times 10^{4}\end{array}$ & $\begin{array}{l}\text { Dzoo } \\
\text { Vzoo } \\
\text { scop } \\
\text { eggs } \\
\text { naup } \\
\text { moll } \\
\text { scru }\end{array}$ & $\begin{array}{l}\mathrm{N} \cdot \mathrm{m}^{-3} \\
\mathrm{ml} \cdot \mathrm{m}^{-3} \\
\mathrm{~N} \cdot \mathrm{m}^{-3} \\
\mathrm{~N} \cdot \mathrm{m}^{-3} \\
\mathrm{~N} \cdot \mathrm{m}^{-3} \\
\mathrm{~N} \cdot \mathrm{m}^{-3} \\
\mathrm{~N} \cdot \mathrm{m}^{-3}\end{array}$ & $\begin{array}{l}23.5 \\
7.3 \\
8.6 \\
2.0 \\
9.1 \\
2.0 \\
0.2\end{array}$ & $\begin{array}{c}31.8 \\
37.3 \\
14.1 \\
2.8 \\
10.8 \\
1.9 \\
0.3\end{array}$ & $\begin{array}{l}24.3 \\
15.7 \\
10.2 \\
2.6 \\
7.1 \\
2.2 \\
0.8\end{array}$ \\
\hline
\end{tabular}


ing bivalve and gastropod veligers, and small crustaceans (Carassou et al., 2009). These zooplankton categories had mean widths, including appendages, of $154.9,65.4,75.4,97.5$ and $176.7 \mu \mathrm{m}$ respectively (Carassou et al., 2009). The densities $\left(\mathrm{N} \cdot \mathrm{m}^{-3}\right)$ of all organisms and of the organisms of the five categories retained were then obtained by taking into account the estimated volume of water filtered by the plankton-net (Table 1).

\section{Data analysis}

The differences in water column conditions and zooplankton amount and composition between bays and between periods were first assessed using a normed principal component analysis (PCA; Legendre and Legendre, 1998). The matrix consisted in a total of 16 variables (columns) and 120 observations (lines). The densities of zooplankton were $\log (\mathrm{x}+1)$ transformed so as to reduce the weight of the most abundant categories (Legendre and Legendre, 1998). The variables which contributed to at least $5 \%$ of the variability on the first two components of the PCA were retained for further analyses. The PCA allowed the correlations between each of the environmental and zooplankton variables to be observed. It also allowed the potential spatial and/or temporal variations of these variables to be detected, as indicated by the relative position of samples from different bays and/ or periods on the first two-dimensional plane of the PCA (Legendre and Legendre, 1998). For each of the water column and zooplankton variables retained, ANOVAs were used to test for the significance of the differences between bays and between months (Scherrer, 1984).

The BIO-ENV procedure (Clarke and Ainsworth, 1993) was then applied to determine which set of variables of the water column and/or the zooplankton best explained the structure of larval fish assemblages in the three bays. This procedure provides a measure of agreement between an environmental and a faunistic matrix, and thus makes it possible to identify the "redundant variables", i.e. those which do not play a role in the "explanation" of biotic patterns when other, more relevant, variables are considered (Clarke and Ainsworth, 1993). First, draftsman plots were used to determine which transformations of environmental data were to be considered (Clarke and Gorley, 2006). $\log (\mathrm{x}+1)$ transformations were applied to almost all water column and zooplankton variables, except for tempera- ture, which had a normal distribution. A normalized Euclidean distance matrix of transformed environmental data was then built. Larval fish abundances were square-root transformed in order to reduce the weight of the very abundant families relative to the rare ones (Legendre and Legendre, 1998). A BrayCurtis similarity matrix of larval abundance was then built. Spearman rank correlations $(\rho)$ between the abiotic and biotic triangular similarity matrices were then computed for all possible combinations of environmental variables, i.e. for different numbers of explanatory variables (Clarke and Ainsworth, 1993). The combination of environmental variables leading to a maximum Spearman rank correlation with a minimum number of variables was retained, and the proportion of water column variables vs. zooplankton variables in this combination was examined. BIO-ENV analyses were performed using Primer v5 (Clarke and Gorley, 2006). Finally, the relationship between the total abundance of fish larvae and the total density of zooplankton was tested within each bay and for the three bays considered together using linear regressions, which were performed using Systat v10.2 @ 2002.

\section{RESULTS}

The PCA on water column and zooplankton variables made it possible to account for $53.4 \%$ of the variability between samples with the first two components. The first axis of the PCA was explained by variations in the density of most zooplanktonic categories, whereas the second axis mainly represented variations in the Chl, POC, PON and POP concentrations (Fig. 2a). Among the nine water column variables, five contributed to over $5 \%$ of the dispersion of the observations on the PCA plane and were retained for the following analyses: temperature, Chl, POC, PON and POP (Fig. 2a). All the zooplankton variables were retained, except for the settled volume (Fig. 2a). Significant differences between bays and between months were observed (ANOVA, $P<0.05$ for all tests) for these five water column and six zooplankton variables. PCA analysis indicated that Chl $a$, POC, PON and POP were highly correlated (Fig. 2a) and varied according to a gradient from Dumbéa to Ouaraï (Fig. 2b), with intermediate values at Chambeyron (Fig. $3 \mathrm{~b}$ to $3 \mathrm{e}$ ). Surface water temperature increased from September to January in the three bays as did the densities 
a)

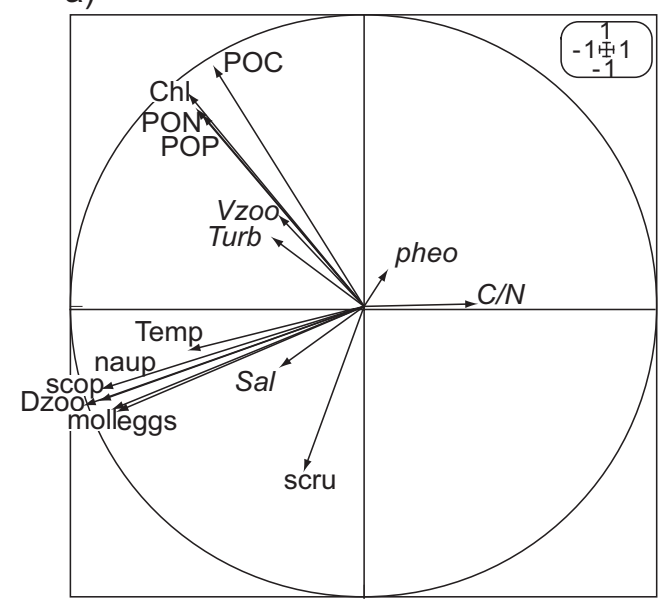

b)

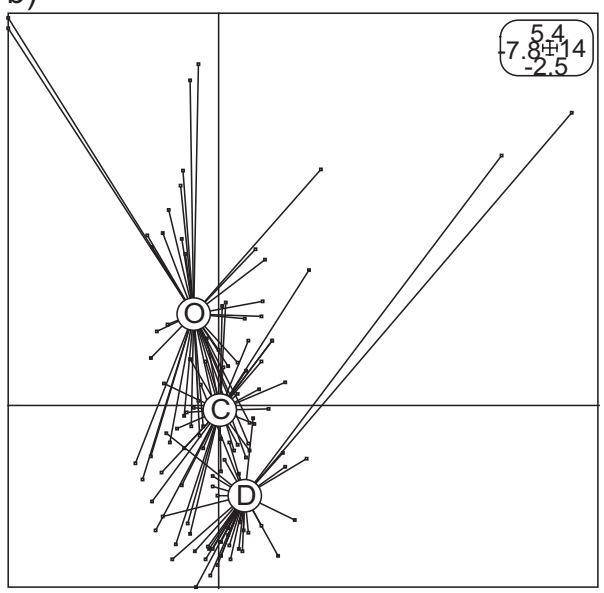

c)

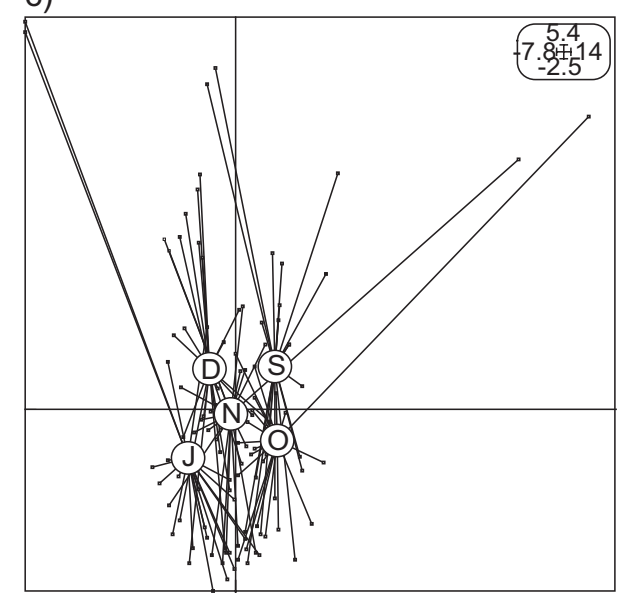

FIG. 2. - Projection of variables and observations on the PC1-PC2 plane of the normed PCA of water column and zooplankton variables with a) correlations between the variables; b) observations grouped by bays, with C: Chambeyron, O: Ouaraï and D: Dumbéa; c) observations grouped by months, with S: September 2005, O: October 2005, N: November 2005, D: December 2005, J: January 2006. Each star represents all the samples from one specific bay or month, the small squares represent the samples. Labels in italics on the correlation circle indicate the variables which had low contributions, i.e. $<5 \%$, on the two components of the analysis. These variables were excluded from further analyses. See Table 1 for variables abbreviations. of total zooplankton and of the five zooplanktonic taxa (Figs. 2a, 2c, 3f-3k). High densities of mollusc larvae and eggs were observed in January in the Bay of Ouaraï (Figs. 2a, 2c, 3i). The densities of total zooplankton and of the five zooplanktonic taxa examined were lower in Dumbéa than in Chambeyron and Ouaraï (Figs. 2a, 2b, 3f-3k).

A total of 7987 fish larvae were collected in the three bays during the sampling period (Table 2). A total of 38 families belonging to ten orders were identified: 28 families in Chambeyron, 16 in Ouaraï and 27 in Dumbéa (Table 2). Among these, Engraulididae were the most frequently encountered in the three bays, followed by Pomacentridae, Clupeidae and Apogonidae in Chambeyron, by Clupeidae, Pomacentridae and Scorpaenidae in Ouaraï, and by Clupeidae, Blenniidae and Pomacentridae in Dumbéa (Fig. 4a). The number of fish larvae collected varied between bays and months, with the highest abundances observed in November, December and January in the bays of Dumbéa, Chambeyron and Ouaraï respectively (Fig. 4b). Fish larvae with a SL of between 10 and $11 \mathrm{~mm}$ were the most abundant when the three bays were considered together (Fig. 5a); however, the size distribution of larvae varied between bays. Most larvae had a SL of between 9 and $11 \mathrm{~mm}$ in Chambeyron and Dumbéa (Fig. 5b and 5d), where they represented $25.3 \%$ and $35.9 \%$ of the total abundance respectively. Larvae with a SL between 27 and $29 \mathrm{~mm}$ were more abundant in the Bay of Ouaraï, where they represented $15.6 \%$ of the larvae (Fig. 5c).

The BIO-ENV analyses showed that a maximum number of five variables was sufficient to explain the structure of larval fish assemblages in all three bays (Table 3 ). Interestingly, these variables differed between bays. When all the bays were considered together as well as in Ouaraï and Dumbéa considered separately there were three to four water column variables, namely Chl, POC, PON (and POP in Ouaraï only), in the combination of variables which best correlated with faunistic data. Conversely, in Chambeyron, four zooplankton variables, namely the densities of nauplii, eggs, small copepods and mollusc larvae, were best correlated with faunistic data (Table 3).

The relationship between the total abundance of fish larvae and the total density of zooplankton was definitely not significant, both when the data from all three bays were compiled, and when the data from each bay were considered separately $(P>0.05$ in all cases, Fig. 4). 

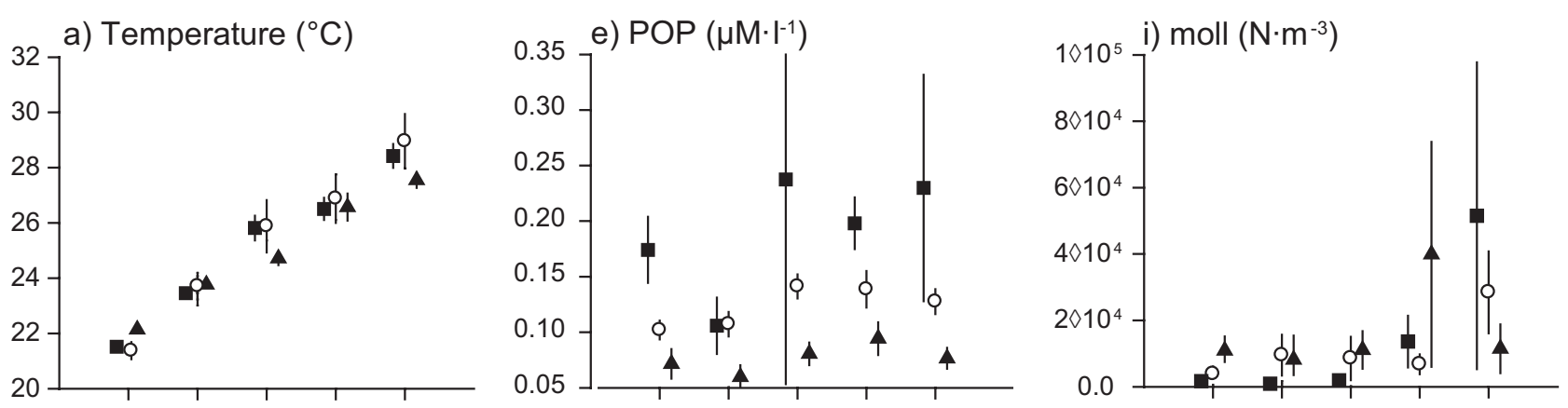

b) $\mathrm{Chl} \mathrm{a}\left(\mu \mathrm{g} \cdot \mathrm{l}^{-1}\right)$
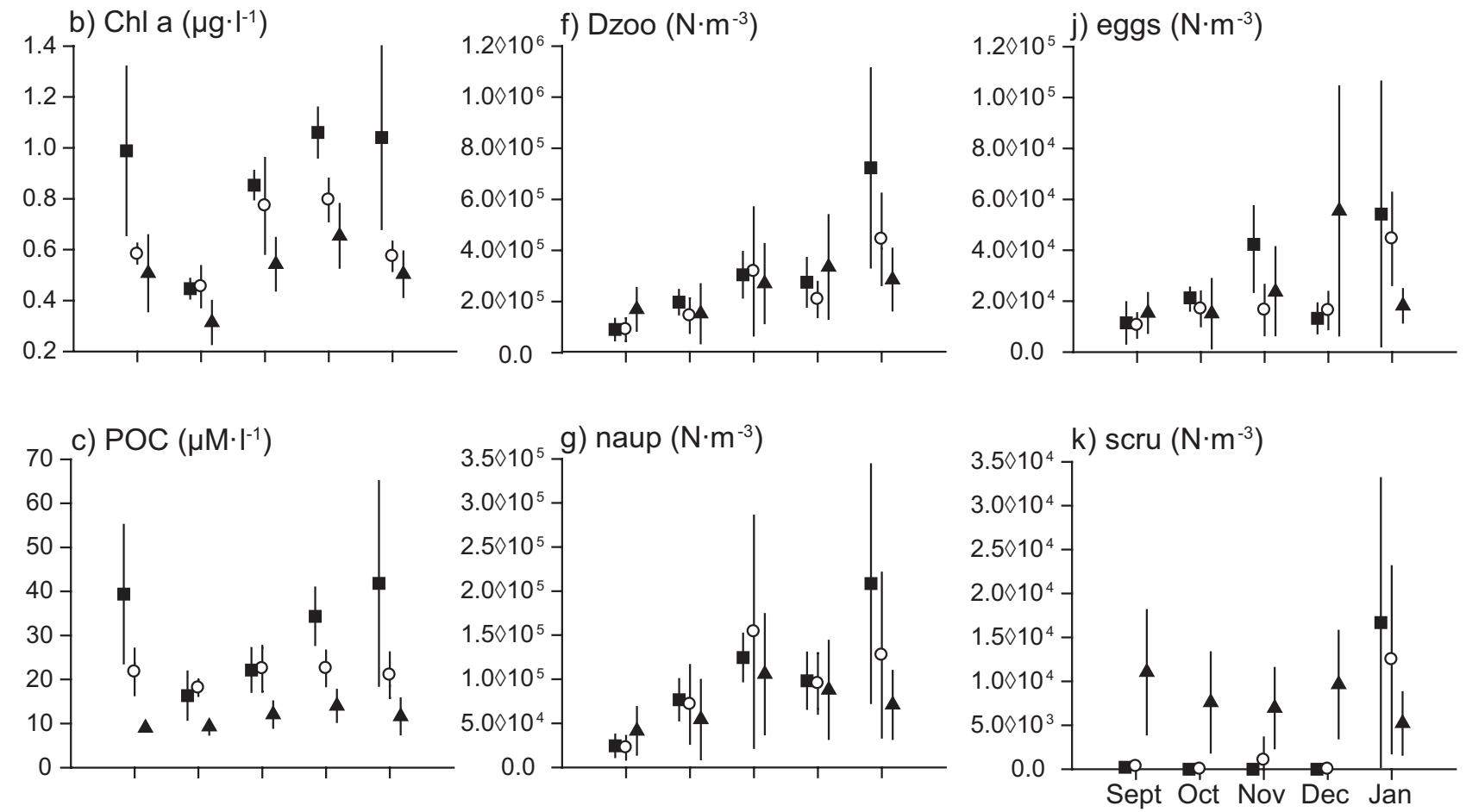

d) PON $\left(\mu \mathrm{M} \cdot \mathrm{I}^{-1}\right)$
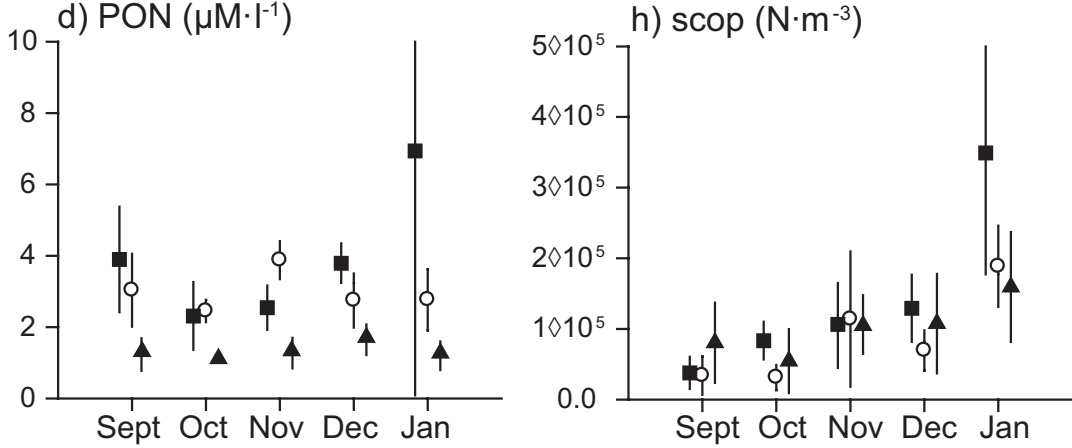

FIG. 3. - Monthly means and standard deviations in each bay for the five water column and six zooplankton variables retained based on their contribution in the PCA (Fig. 2). White circles: Bay of Chambeyron, black squares: Bay of Ouaraï; black triangles: Bay of Dumbéa.

\section{DISCUSSION}

In this study, combinations of up to five environmental variables were shown to correlate significantly with the structures of larval fish assemblages in the three bays under study. In two out of the three bays, the water column factors were more numerous than the zooplankton factors in these combinations of variables. In other words, in these two bays, the amount and composition of zooplankton were less influential in structuring larval assemblages than the water column conditions. Moreover, the relationship 
TABLE 2. - Abundance of larval fish families collected by light-traps in the Bay of Chambeyron (Cham), the Bay of Ouarai (Ouar) and the Bay of Dumbéa (Dumb), from September 2005 to January 2006, with their total abundance (Tot.), average size (SL, mm), and dominant size class, i.e. the more frequently encountered $1 \mathrm{~mm}$ SL class, with the corresponding abbreviations and number of samples performed in each bay. Families are ranked following Nelson (2006).

\begin{tabular}{|c|c|c|c|c|c|c|c|}
\hline $\begin{array}{l}\text { Order } \\
\text { Family }\end{array}$ & code & Cham & $\begin{array}{c}\text { Number of larvae } \\
\text { Ouar }\end{array}$ & Dumb & Tot. & $\begin{array}{l}\text { Average } \\
\text { size }\end{array}$ & $\begin{array}{c}\text { Dominant size } \\
\text { class }\end{array}$ \\
\hline \multicolumn{8}{|l|}{ Anguilliformes } \\
\hline $\begin{array}{l}\text { Congridae } \\
\text { Clupeiformes }\end{array}$ & Cong & 1 & - & - & 1 & 85.0 & - \\
\hline Engraulididae & Engr & 964 & 884 & 2573 & 4421 & 33.1 & $23-24$ \\
\hline Clupeidae & Clup & 162 & 34 & 145 & 341 & 41.0 & $18-19$ \\
\hline \multicolumn{8}{|l|}{ Lophiiformes } \\
\hline $\begin{array}{l}\text { Antennariidae } \\
\text { Atheriniformes }\end{array}$ & Ante & 6 & 6 & - & 12 & 11.1 & $8-9$ \\
\hline Notocheiridae & Noto & 1 & - & 2 & 3 & 8.4 & - \\
\hline Atherinidae & Athe & 136 & - & 7 & 143 & 24.2 & $14-15$ \\
\hline \multicolumn{8}{|l|}{ Beloniformes } \\
\hline $\begin{array}{l}\text { Hemiramphidae } \\
\text { Gasterosteiformes }\end{array}$ & Hemi & - & 1 & - & 1 & 28.4 & - \\
\hline $\begin{array}{l}\text { Syngnathidae } \\
\text { Scorpaeniformes }\end{array}$ & Syng & 34 & - & 41 & 75 & 32.3 & $22-23$ \\
\hline Scorpaenidae & Scor & 6 & 8 & - & 14 & 30.7 & $20-21$ \\
\hline \multicolumn{8}{|l|}{ Perciformes } \\
\hline Serranidae & Serr & 1 & - & - & 1 & 14.2 & - \\
\hline Pseudochromidae & Pseu & 3 & - & - & 3 & 14.6 & - \\
\hline Plesiopidae & Ples & - & - & 5 & 5 & 9.3 & $10-11$ \\
\hline Apogonidae & Apog & 153 & 6 & 79 & 238 & 9.0 & $9-10$ \\
\hline Carangidae & Cara & 25 & 7 & 10 & 42 & 23.9 & $30-31$ \\
\hline Leiognathidae & Leio & - & 1 & 8 & 9 & 4.9 & $6-7$ \\
\hline Lutjanidae & Lutj & 26 & 4 & 51 & 81 & 16.2 & $18-19$ \\
\hline Caesionidae & Caes & 3 & - & - & 3 & 21.3 & - \\
\hline Gerreidae & Gerr & 8 & 1 & 3 & 12 & 10.1 & $11-12$ \\
\hline Haemulidae & Haem & - & - & 21 & 21 & 4.4 & $3-4$ \\
\hline Lethrinidae & Leth & 28 & 5 & 12 & 45 & 16.2 & $18-19$ \\
\hline Mullidae & Mull & 11 & - & 4 & 15 & 30.1 & $29-30$ \\
\hline Chaetodontidae & Chae & 3 & - & - & 3 & 16.6 & - \\
\hline Pomacentridae & Poma & 121 & 10 & 2078 & 2209 & 10.1 & $11-12$ \\
\hline Labridae & Labr & - & - & 1 & 1 & 4.6 & - \\
\hline Scaridae & Scar & - & - & 3 & 3 & 8.1 & - \\
\hline Ammodytidae & Ammo & - & - & 3 & 3 & 5.1 & - \\
\hline Tripterygiidae & Trip & - & - & 22 & 22 & 12.4 & $12-13$ \\
\hline Blenniidae & Blen & 11 & - & 61 & 72 & 14.7 & $16-17$ \\
\hline Gobiesocidae & Gobs & 1 & - & 5 & 6 & 9.1 & $8-9$ \\
\hline Gobiidae & Gobi & 9 & - & 44 & 53 & 6.8 & $6-7$ \\
\hline Schindleriidae & Schi & - & - & 12 & 12 & 14.5 & $15-16$ \\
\hline Siganidae & Siga & 1 & 1 & 8 & 10 & 19.2 & $18-19$ \\
\hline Acanthuridae & Acan & 1 & 1 & - & 2 & 21.6 & - \\
\hline Sphyraenidae & Sphy & 2 & - & - & 2 & 29.4 & - \\
\hline Scombridae & Scom & 2 & 4 & 3 & 9 & 62.9 & $51-52$ \\
\hline \multicolumn{8}{|l|}{ Pleuronectiformes } \\
\hline Bothidae & Both & - & - & 36 & 36 & 11.6 & $11-12$ \\
\hline \multicolumn{8}{|l|}{ Tetraodontiformes } \\
\hline Monacanthidae & Mona & 1 & - & 8 & 9 & 12.1 & $11-12$ \\
\hline Tetraodontidae & Tetr & 4 & 1 & - & 5 & 10.6 & $10-11$ \\
\hline \multirow[t]{2}{*}{ Unidentified } & unid & 2 & 1 & 41 & 44 & n.m & \\
\hline & TOTAL & 1726 & 975 & 5286 & 7987 & 19.4 & $11-12$ \\
\hline \multicolumn{2}{|c|}{ Number of samples } & 40 & 40 & 40 & 120 & & \\
\hline \multicolumn{2}{|c|}{ Number of samples with larvae } & 35 & 34 & 39 & 108 & & \\
\hline
\end{tabular}

between the abundance of fish larvae and the density of their prey was not significant in any of the three bays under study. These results indicate that the hypothesis of a close relationship between the distributions of late-stage larval fish and those of their prey is not supported at the small spatial and temporal scales that were considered in the present study.
This lack of a strong link between the temporal and spatial distributions of larval fish and those of their prey differs from the results obtained elsewhere in the tropics. In the northern Gulf of Mexico, the abundances of pre- and post-flexion larvae of 3 to 5 $\mathrm{mm}$ SL of several species of Carangidae have been shown to vary according to zooplankton biovolume 
a)
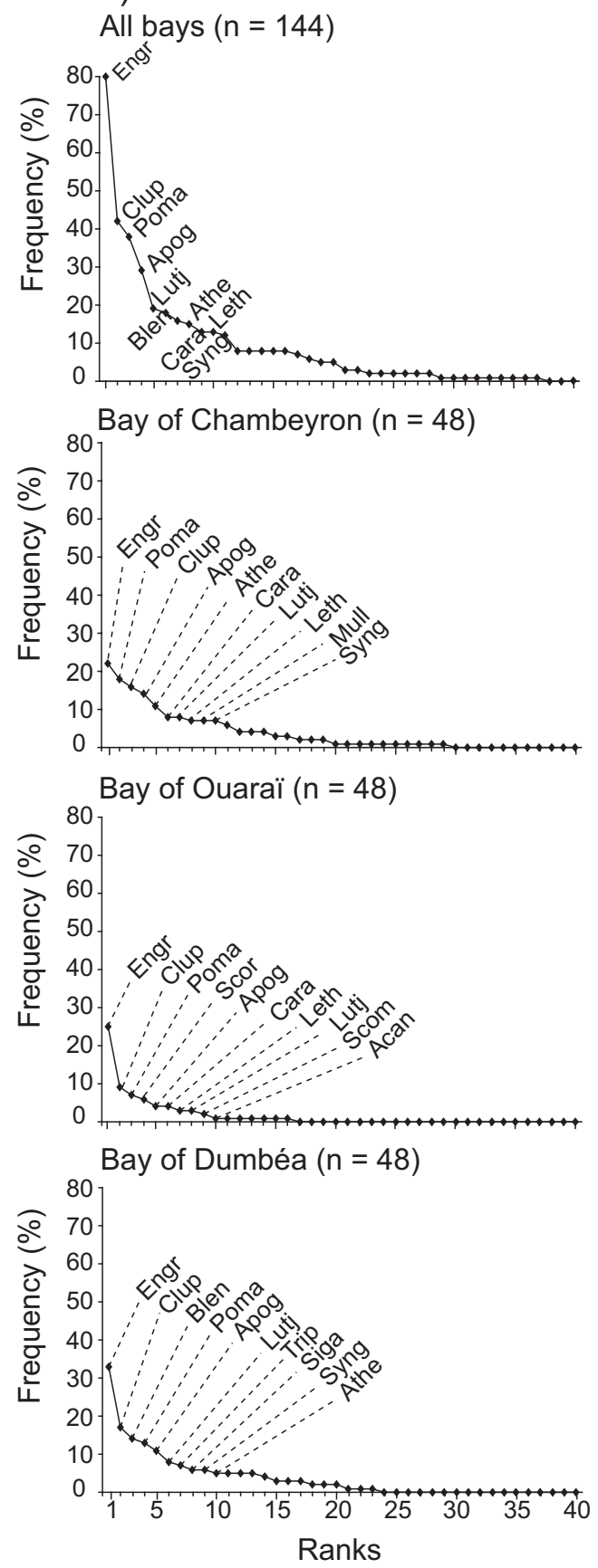

b)
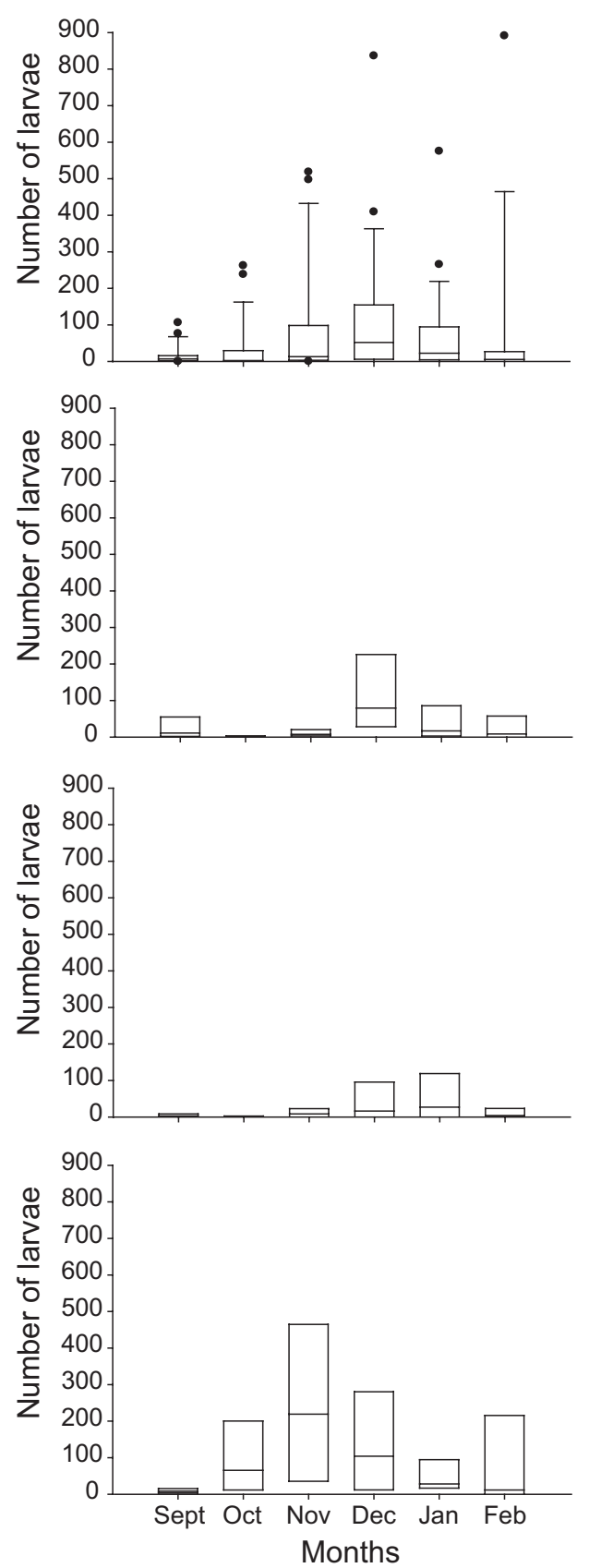

FIG. 4. - Frequency of occurrence of larval fish families (left column) and monthly variations of total larval fish abundance (right column) in a) all bays, b) in the Bay of Chambeyron, c) in the Bay of Ouaraï and d) in the Bay of Dumbéa. See Table 2 for family codes. The upper and lower limits of the box plots (right column) represent the first and third quartiles of larval fish abundance data respectively, the horizontal bars indicate the median, the error bars represent the $10^{\text {th }}$ and $90^{\text {th }}$ percentiles and the dots represent the values outside the $10^{\text {th }}-90^{\text {th }}$ percentile range.

(Ditty et al., 2004). Similarly, Houde and Lovdal (1984) found a significant correlation between the density of 1 to $4 \mathrm{~mm}$ SL pre- and post-flexion larval fish and the density of nauplii of copepods in Biscayne Bay, Florida. Conversely, it has been shown that there is no relationship between the abundance of pre- and post-flexion larvae and zooplankton density in the Gulf of Aden (Ali Khan and Hempel, 1974) and in inshore areas off the Louisiana shelf (Cowan and Shaw, 1991). In a conceptual study of the zooplankton-ichthyoplankton interactions in the pelagic realm, Sanvicente-Añorve et al. (2006) proposed that the relationships between these two assemblages may be either positive, negative, or 

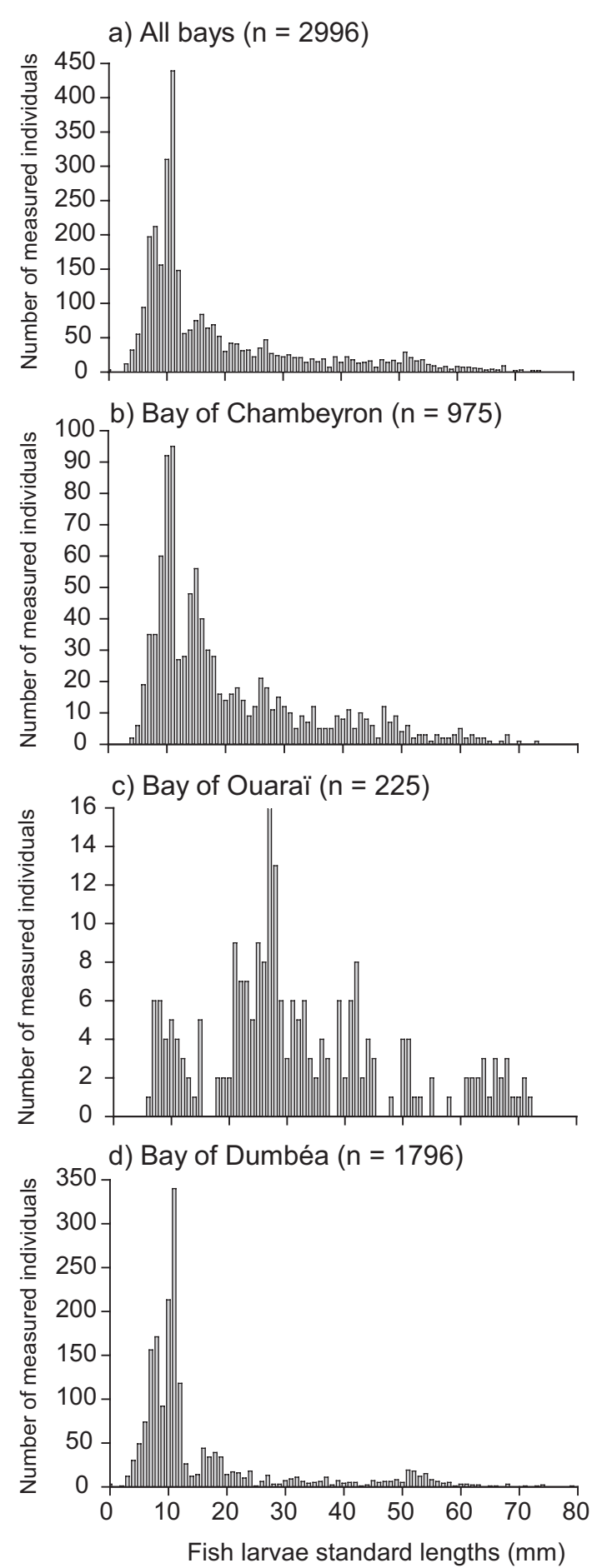

FIG. 5. - Size distribution (standard lengths in $\mathrm{mm}$ ) of fish larvae collected in a) all bays, b) the Bay of Chambeyron, c) the Bay of Ouaraï and d) the Bay of Dumbéa.

follow a random pattern. The type of relationship may vary on a short temporal scale depending on water turbulence or biological interactions such as competition among larvae and predation on them. A positive relationship may occur in the case of a strong predation on fish eggs and larvae and/or
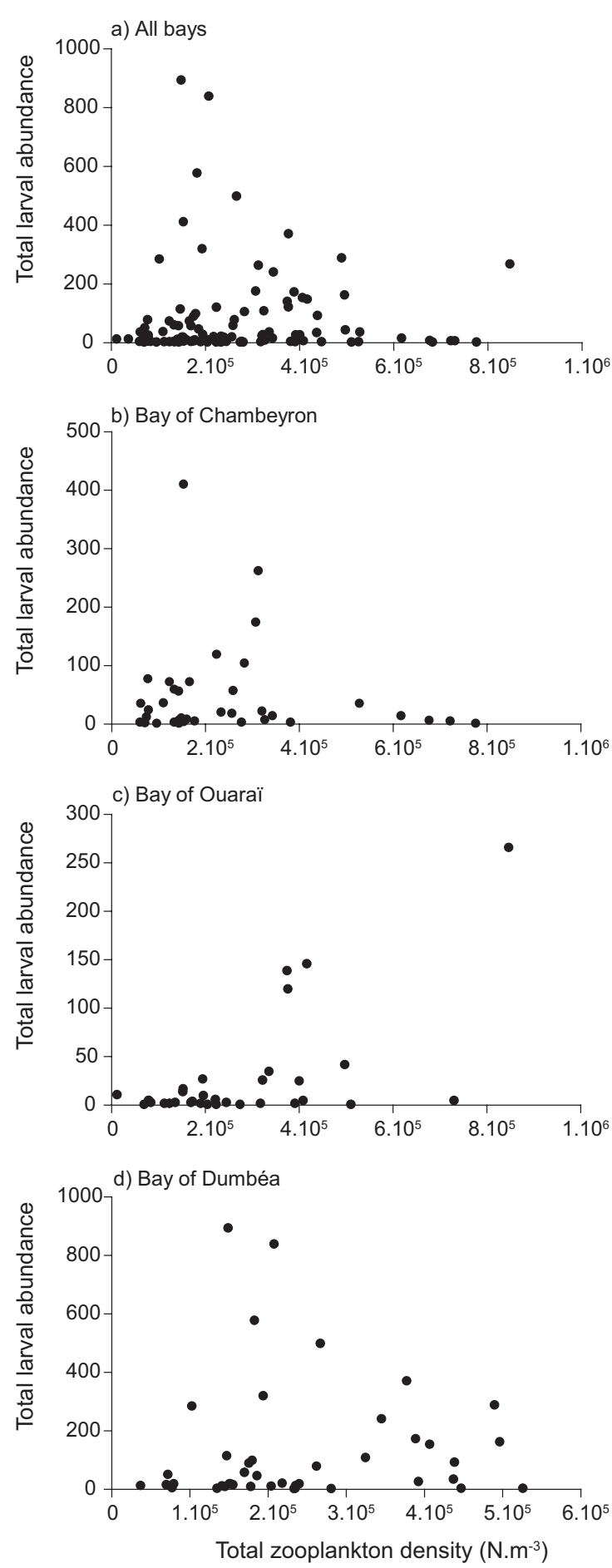

FIG. 6. - Relationship between total larval fish abundance and total zooplankton density at each sampled station in a) the three bays, b) the Bay of Chambeyron, c) the Bay of Ouarai, and d) the Bay of Dumbéa.

strong competition for food between fish larvae. A negative relationship can be expected in the case of a low abundance of fish larvae predators and/or high food availability for fish larvae (i.e. low predation and competition). Finally, the random pattern, i.e. 
TABLE 3. - Combinations of environmental variables, i.e. water column and zooplankton variables, yielding the « best matches » of biotic and abiotic similarity matrices, measured with the standard Spearman coefficient $\rho$, in the BIO-ENV procedure (see text for details). Only the combinations leading to a maximum $\rho$ overall with a minimum number of variables are indicated. See Table 1 for the abbreviations.

\begin{tabular}{lcccc}
\hline Site & $\begin{array}{c}\text { Spearman } \\
\text { coef. } \rho\end{array}$ & $\begin{array}{c}\text { Total number } \\
\text { of variables }\end{array}$ & $\begin{array}{c}\text { Water column } \\
\text { variables }\end{array}$ & $\begin{array}{c}\text { Zooplankton } \\
\text { variables }\end{array}$ \\
\hline All bays & 0.89 & 4 & Chl - POC - PON & Dzoo \\
Bay of Chambeyron & 0.81 & 5 & PON & naup - eggs - scop - moll \\
Bay of Ouaraï & 0.89 & 5 & Chl - POC - PON - POP & Dzoo \\
Bay of Dumbéa & 0.77 & 4 & Chl - POC - PON & Dzoo \\
\hline
\end{tabular}

the absence of any relationship between zoo- and ichthyoplankton assemblages, may correspond to a transition state between the positive and negative patterns (Sanvicente-Añorve et al., 2006). This transitional state may be explained either by the effect of water turbulence, winds or river discharge in coastal waters, all of which generate random movement in animals, or by the behaviour of ichthyoplankton linked to their ontogenetic stage. The latter explanation seems to be more adapted to our results since the fish larvae we sampled were much larger and consequently much more developed than those that were sampled in the studies cited above (including Sanvicente-Añorve et al., 2006). Late-stage larvae of coral reef fish are characterized by highly developed sensory and swimming abilities (Fisher and Bellwood, 2002; Leis, 2006), which enable them to orientate actively in the pelagic environment, and to detect and catch their prey much more efficiently than smaller larvae. The differences in behaviour between late-stage fish larvae, which move actively in the water column, and zooplankton organisms, which passively drift with currents, may explain the observed lack of relationships in their abundances.

This lack of relationship between larval fish and zooplankton assemblage structures also suggests that detecting potential relationships between the two assemblages depends on the spatial scale considered. In a previous study conducted from the coast to the barrier reef of New Caledonia, the spatial variations of larval fish abundances were shown to correlate with the spatial variations of chlorophyll, concentrations of particulate organic matter and zooplankton density (Carassou et al., 2008). Since the present study was conducted at a smaller spatial scale, i.e. that of coastal embayments, the spatial variations in water column conditions, zooplankton and larval fish assemblages might have been insufficient to allow any significant co-variations to be detected. Fi- nally, the fact that water column conditions, such as Chla, explain the larval fish distribution better than zooplankton density does, may be due to the patchy distribution of zooplankton assemblages (Omori and Hammer, 1982), whereas Chl $a$ and particulate organic matter concentrations give a more continuous measure of water column conditions.

Another interesting result found in this study is that Chambeyron was the only bay in which zooplankton variables could be identified as important factors for structuring larval fish assemblages. This might be due to the relatively homogeneous environmental conditions observed in Chambeyron, whereas the other two bays were characterized by more contrasted Chla and particulate organic matter concentrations between stations. This spatial variability might have generated a stronger link with the water column factors in these two bays, whereas in Chambeyron, the zooplankton variables varied more in space than the water column factors, resulting in a higher contribution of zooplankton variables to the matching faunistic data.

As suggested by Bailey and Houde (1989), the importance of food availability for larval fish survival and recruitment may vary depending on species and environment, and also on the developmental stage of the larvae considered. This study suggests that the well-developed swimming and sensory abilities of late-stage larvae of coral reef fish may interact with the more passive drift of their food, so that the relationship between these larvae and their prey is most likely complex, non-linear and variable between taxa and ranges of environmental conditions.

\section{ACKNOWLEDGEMENTS}

This study was funded by IRD, the Programme d'Évaluation des Ressources Marines de la Zone 
Économique Exclusive de Nouvelle-Calédonie (Zonéco), and the French National Programme d'Environnement Côtier (PNEC). We are most grateful to Joseph Baly for the adaptation of the lighttraps and most of the field sampling and laboratory work. We would like to thank Gérard Mou-Tham for help in field sampling, and Nathalie Favéro, Sophie Hénin, Adrien Bertaud, Maël Imirizaldu and Emelyne Rolland for counting, identifying and measuring zooplankton. Philippe Gérard (IRD) performed chemical measurements. Dr Robert Le Borgne (IRD) provided precious help for zooplankton identification. We also thank the different captains of the research vessels Coris and Aldric: Miguel Clarque, Napoléon Colombani and Samuel Tereua. AnneMarie Lassallette (University of the French West Indies) helped in editing the English text. Haizea Jimenez (IRD Nouméa) helped in the Spanish translation of the title, summary and keywords. We also wish to thank three anonymous reviewers for their comments and detailed suggestions.

\section{REFERENCES}

Ali Khan, J. and G. Hempel. - 1974. Relation of fish larvae and zooplankton biomass in the Gulf of Aden. Mar. Biol., 28: 311-316.

Aminot, A. and R. Kérouel. - 2004. Hydrologie des écosystèmes marins. Paramètres et analyses. Éditions Ifremer, Brest.

Bailey, K.M. and E.D.Houde. - 1989. Predation on eggs and larvae of marine fishes and the recruitment problem. Adv. Mar. Biol., 25: $1-83$.

Brander, K.M., R.R.Dickson, and J.G. Shepherd. - 2001. Modeling the timing of plankton production and its effect on recruitment of cod (Gadus morhua). ICES J. Mar. Sci., 85: 962-966.

Carassou, L. - 2008. Les assemblages de larves de poissons dans le lagon de Nouvelle-Calédonie: structure spatio-temporelle et relations avec les facteurs abiotiques et biotiques de l'environnement. Ph.D. thesis, École Pratique des Hautes Études Perpignan.

Carassou, L. and D. Ponton. - 2007. Spatio-temporal structure of pelagic larval and juvenile fish assemblages in coastal areas of New Caledonia, southwest Pacific. Mar. Biol., 150: 697-711.

Carassou, L., D. Ponton, C. Mellin and R. Galzin. - 2008. Predicting the structure of larval fish assemblages structure by a hierarchical classification of meteorological and water column forcing factors. Coral Reefs, 27: 867-880.

Carassou L., R. Le Borgne and D. Ponton. - 2009. Diet of pre-settlement larvae of coral-reef fish: selection of prey types and sizes. J. Fish Biol., in press. doi: 10.1111/j.1095-8649.2009.02312.x, available on line at http://www.blackwell-synergy.com.

Choat, J.H., P.J. Doherty, B.A. Kerrigan and J.M. Leis. - 1993. A comparison of towed nets, purse seine and light-aggregation devices for sampling larvae and pelagic juveniles of coral reef fishes. Fish. Bull., 91: 195-209.

Clarke, K.R. and M. Ainsworth. - 1993. A method of linking multivariate community structure to environmental variables. Mar. Ecol. Prog. Ser., 92: 205-219.

Clarke, K.R. and R.N. Gorley. - 2006. PRIMERv5: User manual/ Tutorial. Primer-E: Plymouth Routines in Multivariate Ecological Research.

Cowan, J.H. and R.F. Shaw. - 1991. Ichthyoplankton off west Louisiana in winter 1981-1982 and its relationship with zooplankton biomass. Contrib. Mar. Sci., 32: 103-121.
Cushing, D.H. - 1975. Marine ecology and fisheries. Cambridge University Press, Cambridge.

Cushing, D.H. - 1990. Plankton production and year-class strength in fish populations: an update of the match/mismatch hypothesis. Adv Mar Biol., 26: 250-293.

Ditty, J.G., R.F. Shaw and J.S. Cope. - 2004. Distribution of carangid larvae (Teleostei: Carangidae) and concentrations of zooplankton in the northern Gulf of Mexico, with illustrations of early Hemicaranx amblyrhynchus and Caranx spp. larvae. Mar Biol., 145: 1001-1014.

Doherty, P.J. - 1987. Light-traps: selective but useful devices for quantifying the distributions and abundances of larval-fishes. Bull. Mar. Sci. 41: 423-431.

Doherty, P.J. and J.H. Carleton. - 1997. The distribution and abundance of pelagic juvenile fish near Grub Reef, Central Great Barrier Reef. In: H.A. Lessios and I.G. Macintyre (eds.) Proc. $8^{\text {th }}$ Int. Coral Reef Sym. Vol 2, pp. 1155-1160. Smithsonian Tropical Research Institute, Panama.

Fisher, R., and D.R. Bellwood. - 2002. The influence of swimming speed on sustained swimming performance of late-stage reef fish larvae. Mar. Biol., 140: 801-807.

Haney, J.F. - 1988. Diel patterns of zooplankton behavior. Bull. Mar. Sci., 43: 583-603.

Harden-Jones, F.R. - 1968. Fish migration. Edward Arnold Publishers, London.

Hartmann, J. - 1983. Two feeding strategies of young fishes. Arch. Hydrobiol., 96(4): 496-509.

Houde, E.D. and J.A. Lovdal. - 1984. Seasonality of occurrence, foods and food preferences of ichthyoplankton in Biscayne Bay, Florida. Est. Coast. Shelf Sci., 18: 403-419.

Legendre, P. and L. Legendre. - 1998. Numerical Ecology, Elsevier Science, Amsterdam.

Leis, J.M. - 1991. The pelagic stage of reef fishes: the larval biology of coral reef fishes. In: Sale PF (ed.), The Ecology of Fishes on Coral Reefs, pp. 183-227. Academic Press, San Diego.

Leis, J.M. - 2006. Are larvae of demersal fishes plankton or nekton? Adv. Mar. Biol., 51: 59-141.

Leis, J.M. and B.M. Carson-Ewart (eds). - 2000. The larvae of IndoPacific Coastal Fishes, an identification guide to marine fish larvae. Fauna Melanesia Handbooks vol 2, Australian Museum, Sydney.

Leis, J.M. and T. Trnski. - 1989. The larvae of Indo-Pacific shorefishes. New South Wales University Press, Kensington.

McCormick, M.I. and B.W. Molony. - 1992. Effects of feeding history on the growth characteristics of a reef fish at settlement. Mar. Biol., 114: 165-173.

Meekan, M.G., J.H. Carleton, C.R. Steinberg, A.D. McKinnon, R. Brinkman, P.J. Doherty, A. Halford, S. Duggan and L. Mason. - 2006. Turbulent mixing and mesoscale distributions of latestage fish larvae on the NW Shelf of Western Australia. Fish. Oceanogr. 15: 44-59.

Nelson, J.S. - 2006. Fishes of the world. John Wiley \& Sons, Hoboken.

Omori, M. and W.M. Hammer. - 1982. Patchy distribution of zooplankton: behavior, population assessment and sampling problems. Mar. Biol., 72: 193-200

Pepin, P., J.F. Dower and F.J.M. Davidson. - 2003. A spatially explicit study of prey-predator interactions in larval fish: assessing the influence of food and predator abundance on larval growth and survival. Fish. Oceanogr., 12: 19-33.

Sampey, A., A.D. McKinnon, M.G. Meekan and M.I. McCormick. -2007. Glimpse into guts: overview of the feeding of larvae of tropical shorefishes. Mar. Ecol. Prog. Ser., 339: 243-257.

Sanvicente-Añorve, L., L.A. Loto, M.L. Espinosa-Fuentes and C. Flores-Coto. - 2006. Relationship patterns between ichthyoplankton and zooplankton: a conceptual model. Hydrobiologia, 559: 11-22.

Scherrer, B. - 1984. Boistatistique. Gaëtan Morin Editions, Boucherville.

Voss R., C. Clemmesen, H. Baumann and H.H. Hinrichsen. - 2006. Baltic sprat larvae: coupling food availability, larval condition and survival. Mar. Ecol. Prog. Ser., 308: 243-254.

Wilson, D.T. - 2001. Patterns of replenishment of coral-reef fishes in the nearshore waters of the San Blas Archipelago, Carribean Panama. Mar. Biol., 139: 735-753.

Received November 14, 2008. Accepted June 26, 2009.

Published online October 5, 2009. 